International Journal of Language Education

Volume 5, Number 3, 2021, pp. 125-134

ISSN: $2548-8457$ (Print) 2548-8465 (Online)

Doi: https://doi.org/10.26858/ijole.v5i3.20239

\title{
Integrating Linguistics Theories in Developing Foreign Language Teaching Material (German Grammar Textbook for Indonesian Learners)
}

\author{
Mantasiah R. \\ Universitas Negeri Makassar, Indonesia \\ Email:mantasiah@unm.ac.id \\ Yusri \\ Universitas Negeri Makassar, Indonesia \\ Email:yusriugm@gmail.com \\ Muhammad Anwar \\ Universitas Negeri Makassar, Indonesia \\ Email:muh.anwar@unm.ac.id \\ Hasmawati \\ Universitas Negeri Makassar, Indonesia \\ Email:hasmawati@unm.ac.id
}

Received: 19 April 2021

Reviewed: 1 August 2021

Accepted: 1 October 2021

\begin{abstract}
This study aims to investigate the effectiveness of German grammar textbook using linguistic approaches in increasing students' academic motivation, learning outcome, and linguistic understanding. This German grammar textbook is composed for Indonesian learners. This study employed experimental approach by involving two experimental groups without control group. The total research participants were 45 Indonesian students in the second semester of the German language education department divided into two classes. There were three variables observed in this study. Students' learning outcome was measured by a grammar test developed by the researchers, while students' academic motivation was measured using a scale developed by Vallerand et al. (1992) consisting of 28 items that had been translated into Indonesian and tested by Natalya \& Purwanto (2018). Students' linguistic understanding was measured using the linguistic understanding scale developed by Hasmawati (2021). The treatment was conducted in six meetings in which each meeting took place for two hours using Zoom video conference platform. Data were analyzed using a descriptive statistic, a correlation test, and a paired sample t-test using the SPSS-26 application. The study found that the integration of linguistic approach, error analysis and contrastive analysis, in composing a grammar textbook of a foreign language is more likely to positively affect students' academic motivation, learning outcome, and linguistic understanding.
\end{abstract}

Keywords: linguistics; foreign language; teaching materials. 


\section{Introduction}

Foreign language teaching is an important topic that has been studied by numerous researchers. This is because a growing number of people are interested in becoming a bilingual or multilingual (Zhou, 2020 \& Lo Bianco \& Slaughter, 2017). Besides, foreign language proficiency has become one of the significant contributors to a person's career advancement (Wiens et al., 2018; Kissau et al., 2019; Saito \& Maeda, 2018). Some factors play a vital role in foreign language teaching, such as learning method (Suparsa et al., 2017; Romadloni et al., 2017; Rosmaladewi \& Abduh, 2017); teacher quality (Staub \& Kirkgöz, 2019; Drakulić, 2019); learning media (Dewi et al., 2020; Malik et al., 2019); and teaching materials (Ismail et al., 2020; Mantasiah, 2020).

Among those factors, the development of learning method and learning media has received greater attention from previous researchers. On the other hand, little attention has been given to the development of teaching materials. The selection and development of teaching materials should also be highly regarded in foreign language teaching. Failure in choosing or developing teaching materials that suit learners' needs can negatively affect the quality of learning (Mantasiah et al., 2020; Nazila et al., 2020; Nurhikmah et al., 2021). Thus, a foreign language teacher is required to be competent for developing teaching materials based on needs analysis conducted on his/her students. Teacher should not simply use teaching materials that have been provided by the school or available in the Internet as competency standards used and student characteristics may be different.

In developing teaching materials, especially about grammar, several aspects should be observed; one of which is the use of linguistic approach in grammar elucidation. Previous studies have suggested that linguistic understanding can help students understand grammar more readily (Mantasiah et al., 2018; Mantasiah et al., 2020). This is in line with the arguments from Jabbarova (2020), Melo-Pfeifer \& Chik (2020), Hasmawati et al. (2020) that linguistics and foreign language learning are inextricably linked. Thus, students are expected to understand the linguistic concepts of the target language in their learning process. Some linguistic approaches can be used in developing teaching materials; one of which is error analysis. This method has been used by numerous researchers to investigate the errors made by language learners both in spoken and written texts (Karim et al., 2018; Uysal \& Aysin, 2017; Suhono, 2017). However, those studies tended to be concluded upon identifying errors; only a few studies have deployed their findings in creating foreign language teaching materials.

Besides error analysis, another approach that can be used is contrastive analysis. This approach focuses on the comparison of two or more languages. By using this approach, learners are able to discover the similarities and differences between their first language and target language. The similarities and differences between those languages are described through linguistics by explicating the linguistics process of both languages. Thus, the comprehension of basic linguistics and linguistic process is required when this approach is implemented. Contrastive analysis in foreign language teaching has been widely used by some researchers (Khansir \& Pakdel, 2019; Chen, 2020; Soler \& Tecedor, 2018). However, little research has been found to use their contrastive analysis research findings to develop teaching materials for foreign language learners.

The current study is the last stage in developing a German grammar textbook which applies linguistics approach. Learners' need analysis was conducted at the first stage. The findings later became the basis for developing the textbook. The study was conducted by employing error analysis to identify students' error tendencies in learning German. Moreover, contrastive analysis of Indonesian and German was also conducted at the first stage. Through contrastive analysis, 
linguistic phenomena of German can be found and used as the focus of a grammar textbook (Mantasiah et al., 2019; Mantasiah et al., 2020). At the second stage, teaching materials were assessed using expert judgment and tested on students to collect their responses about the textbook before it was used in the real teaching and learning processes. The findings of the second stage showed that the German grammar textbook being developed was appropriate after some minor revisions. (Mantasiah, et al., 2020). The current study aims to investigate the effectiveness of German grammar textbook based on a linguistic approach in increasing students' academic motivation, learning outcome, and linguistic understanding. Therefore, the focus of this study is to investigate the effectiveness of the German grammar textbook based on a linguistic approach in increasing students' academic motivation, and learning outcome. The German grammar textbook is developed for Indonesian learners.

\section{Research method}

Research design

This study employed experimental approach by involving two experimental groups without control group. By taking students' learning process into consideration, the current study was conducted as the students were having classes as usual. As a result, no control group was included in this research. Control group can hinder teaching and learning process in the classroom and generate different learning outcome, which later can be disadvantageous for the students in the control group.

\section{Participants}

The participants of this study were Indonesian students in the second semester of the German language education department in one of Indonesia universities. A total of 45 participants involved in this research were divided into two groups (Group 1: 25 students, Group II: 20 students). Prior to the research, the students were given explanation about this research and asked about their consent to participate.

Research variable and data collection

There were three variables observed in this study, namely students' learning outcome, academic motivation, and linguistic understanding. The observation on the learning outcome was focused on the students' writing skill. It was due to consideration that writing skill is highly affected by the use of correct grammar and the textbook being developed is a grammar book. This variable was measured by using a grammar test developed by the researchers who were the lecturers at the same department with the participants. The second variable was students' academic motivation measured using a scale developed by Vallerand et al. (1992). This scale had been translated into Indonesian and tested by Natalya \& Purwanto (2018). This scale consisted of 30 items which were categorized into 3 general dimensions (intrinsic, extrinsic, and amotivational). The results showed that all of the dimensions had Cronbach's alpha values greater than $0.7(\alpha \geq 0.7)$, indicating that the scale was reliable to be used for assessing the research participants. The third variable was students' linguistic understanding measured using a linguistic understanding scale developed by Hasmawati et al. (2021). This scale consisted of 14 items which were categorized into 4 dimensions, namely phonology, morphology, syntax, and semantics. All of the items in this scale had Cronbach's alpha values greater than $0.7(\alpha \geq 0.7)$. 
Research procedure

The treatment was performed online due to the Covid-19 pandemic. The teaching and learning processes were conducted in six meetings in which each meeting took place for two hours using Zoom video conference platform. Prior to the treatment, the students were given a pretest in the forms of grammar, academic motivation scale, and linguistics understanding scale tests. After six meetings, the students took a posttest.

\section{Data analysis}

Analysis of descriptive statistic data was conducted to find out the average score of the students' learning outcome, academic motivation, and linguistics understanding, either before or after the treatment. In addition, to examine the significance of students' learning outcome, academic motivation, and linguistics understanding before and after the treatment, an inferential statistical analysis using paired sample t-test was performed. Since the focus of this research was also to discover the correlation among the three variables, a correlation test was carried out. All of the data analysis processes were conducted using SPAA-26 computer software..

\section{Findings and discussion}

Students' academic motivation in learning german grammar

The students' academic motivation variable was primarily focused on academic motivation in learning German grammar, so some statements in the scale had been adjusted to this context. Table 1 shows the comparison between students' academic motivation before and after the treatment.

Table 1. Paired Sample Statistics

\begin{tabular}{lllccc}
\hline & Mean & $\mathrm{N}$ & $\begin{array}{c}\text { Std. } \\
\text { Deviation }\end{array}$ & $\begin{array}{c}\text { Std. Error } \\
\text { Mean }\end{array}$ \\
\hline Pair 1 & Posttest & 112.07 & 45 & 9.024 & 1.345 \\
\cline { 2 - 6 } & Pretest & 101.84 & 45 & 8.307 & 1.238 \\
\hline
\end{tabular}

Table 1 shows that there was an increase in students' academic motivation as much as 10.22. The highest score in this scale is 150 , showing that students' academic motivation increased by $6.81 \%$. Table 2 below describes if the increase was significant or not.

Table 2. The Results of Paired Sample Test

\begin{tabular}{|c|c|c|c|c|c|c|c|c|c|}
\hline & & \multicolumn{5}{|c|}{ Paired Differences } & \multirow{3}{*}{$\mathrm{t}$} & \multirow{3}{*}{ df } & \multirow{3}{*}{ Sig. } \\
\hline & & \multirow[t]{2}{*}{ Mean } & \multirow[t]{2}{*}{$\begin{array}{c}\text { Std. } \\
\text { Deviation }\end{array}$} & \multirow{2}{*}{$\begin{array}{l}\text { Std. } \\
\text { Error } \\
\text { Mean }\end{array}$} & \multicolumn{2}{|c|}{$\begin{array}{l}95 \% \text { Confidence } \\
\text { Interval of the } \\
\text { Difference }\end{array}$} & & & \\
\hline & & & & & Lower & Upper & & & \\
\hline $\begin{array}{c}\text { Pair } \\
1\end{array}$ & $\begin{array}{l}\text { Posttest } \\
\text { - Pretest }\end{array}$ & 10.22 & 7.459 & 1.112 & 7.981 & 12.463 & 9.194 & 44 & .000 \\
\hline
\end{tabular}

Table 2 shows that the significance value $(0.00)$ is lower than the used standard significance value (0.05). It proves that the increase in students' academic motivation in learning German grammar was significant, and it might happen due to the teaching materials used in this study. 
The German grammar comprehension

The other variable observed in this study was students' learning outcome in learning German grammar. Table 3 shows the comparison between students' academic motivation before and after the treatment.

Table 3. Paired Sample Statistics

\begin{tabular}{llrrrr}
\hline & & Mean & $\mathrm{N}$ & $\begin{array}{c}\text { Std. } \\
\text { Deviation }\end{array}$ & \multicolumn{1}{c}{$\begin{array}{c}\text { Std. Error } \\
\text { Mean }\end{array}$} \\
\hline Pair 1 & Posttest & 69.78 & 45 & 7.830 & 1.167 \\
\cline { 2 - 6 } & Pretest & 64.11 & 45 & 8.139 & 1.213 \\
\hline
\end{tabular}

Table 3 shows that there was an increase in students' learning outcome with the score of 5.667 after the treatment. The maximum score in this scale is 100 and it can be concluded that students' learning outcome increased as much as 5.667\%. Table 4 below describes the significance state of the increase.

Table 4. The Results of Paired Samples Test

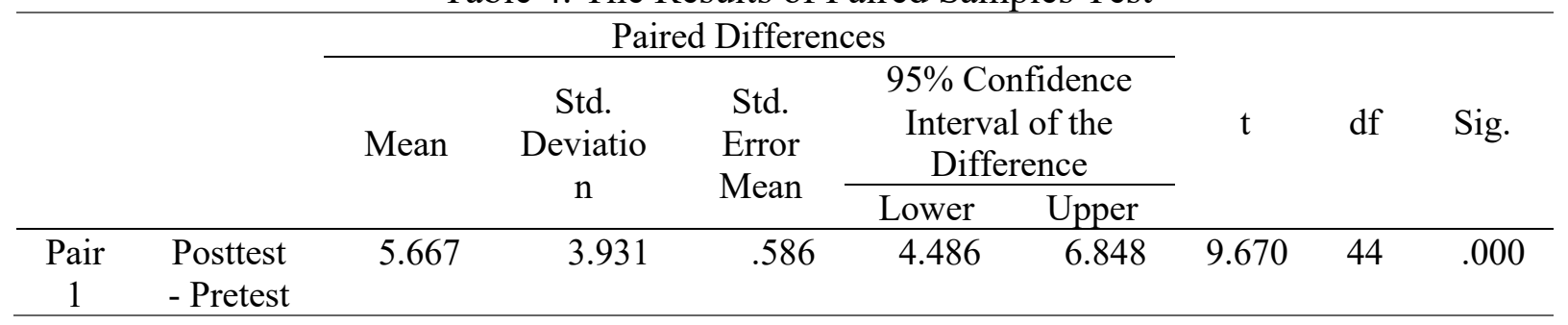

Table 4 shows that the significance value is 0.00 . The significance value is lower than the standard significance value (0.05). It shows that there was a significant increase in students' German grammar understanding after the treatment was given.

Linguistics understanding

This variable means that at the very least the students need to know the basic linguistic processes found in the text when they learn the grammar, whether it is related to the phonological, morphological, syntactical, or semantic level. The increase in students' linguistic understanding can be seen in Table 5:

Table 5. Paired Sample Statistics

\begin{tabular}{lllrrr}
\hline & Mean & N & \multicolumn{2}{c}{$\begin{array}{c}\text { Std. } \\
\text { Deviation }\end{array}$} & \multicolumn{2}{c}{$\begin{array}{c}\text { Std. Error } \\
\text { Mean }\end{array}$} \\
\hline \multirow{2}{*}{ Pair 1 } & Posttest & 42.13 & 45 & 4.121 & .614 \\
\cline { 2 - 6 } & Pretest & 35.56 & 45 & 2.073 & .309 \\
\hline
\end{tabular}

Table 5 shows that the average pretest score was 35.56 with 70 as the highest score, indicating that before the treatment process, students' linguistic understanding was low since it did not reach $50 \%$ of the maximum score of the scale. The comparison of the pretest and posttest data in Table 5 shows that there was an increase in students' linguistic understanding with the score of 6.578 with the percentage of the increase $9.39 \%$. 
Table 6. The Results of Paired Samples Test

\begin{tabular}{|c|c|c|c|c|c|c|c|c|c|}
\hline & & \multicolumn{5}{|c|}{ Paired Differences } & \multirow{3}{*}{$\mathrm{t}$} & \multirow{3}{*}{$\mathrm{df}$} & \multirow{3}{*}{ Sig. } \\
\hline & & \multirow[t]{2}{*}{ Mean } & \multirow{2}{*}{$\begin{array}{c}\text { Std. } \\
\text { Deviatio } \\
n\end{array}$} & \multirow{2}{*}{$\begin{array}{l}\text { Std. } \\
\text { Error } \\
\text { Mean }\end{array}$} & \multicolumn{2}{|c|}{$\begin{array}{l}\text { 95\% Confidence } \\
\text { Interval of the } \\
\text { Difference }\end{array}$} & & & \\
\hline & & & & & Lower & Upper & & & \\
\hline $\begin{array}{c}\text { Pair } \\
1\end{array}$ & $\begin{array}{c}\text { Posttest - } \\
\text { Pretest }\end{array}$ & 6.578 & 5.070 & .756 & 5.055 & 8.101 & 8.703 & 44 & .000 \\
\hline
\end{tabular}

The significance value in Table $6(0.00)$ is lower than the used significance standard $(0.05)$. It means that there was a significant increase in students' linguistic understanding after the treatment process.

The correlations among the variables

Correlation test was conducted to know whether there was a correlation among the variables of this study. The data are used to comprehensively explain all of the data found in this research.

Table 7. The Results of Correlation Analysis of the Variables

\begin{tabular}{|c|c|c|c|c|}
\hline \multicolumn{5}{|c|}{ Correlations } \\
\hline & & $\begin{array}{l}\text { Academic } \\
\text { Motivation }\end{array}$ & $\begin{array}{l}\text { Learning } \\
\text { Outcome }\end{array}$ & $\begin{array}{l}\text { Linguistic } \\
\text { Understanding }\end{array}$ \\
\hline \multirow[t]{3}{*}{ Academic Motivation } & $\begin{array}{l}\text { Pearson } \\
\text { Correlation }\end{array}$ & 1 & $.796^{* *}$ & .094 \\
\hline & Sig. (2-tailed) & & .002 & .538 \\
\hline & $\mathrm{N}$ & 45 & 45 & 45 \\
\hline \multirow[t]{3}{*}{ Learning Outcome } & $\begin{array}{l}\text { Pearson } \\
\text { Correlation }\end{array}$ & $.796^{* *}$ & 1 & $.752^{* *}$ \\
\hline & Sig. (2-tailed) & .002 & & .004 \\
\hline & $\mathrm{N}$ & 45 & 45 & 45 \\
\hline \multirow[t]{3}{*}{$\begin{array}{l}\text { Linguistic } \\
\text { Understanding }\end{array}$} & $\begin{array}{l}\text { Pearson } \\
\text { Correlation }\end{array}$ & .094 & $.752^{* *}$ & 1 \\
\hline & Sig. (2-tailed) & .538 & .004 & \\
\hline & $\mathrm{N}$ & 45 & 45 & 45 \\
\hline
\end{tabular}

Table 7 shows that two pairs of variables are correlated. The first correlation is between learning outcome and academic motivation variables. The significance value of the two variables $(0.002)$ is lower than the standard significance value (0.05). It means that the higher students' academic motivation, the better the learning outcome. The second correlation was found between the linguistic understanding and the learning outcome. The significance value of the two variables (0.004) is lower than the standard significance value $(0.05)$, meaning that students with better linguistic understanding tend to have better German grammar comprehension.

\section{Discussion}

Students tend to believe that grammar is the most difficult material to comprehend among others. However, grammar should serve as the basis of understanding language skills such as speaking, writing, and reading. Students' judgment of the grammar surely affects their academic motivation in learning the materials. This can be seen from the pretest results before the treatment 
in which the students' academic motivation was only $65 \%$ from the maximum score. This is in line with the arguments from Vannestål \& Lindquist (2007) and Dehghani et al. (2016) that grammar class is frequently assumed to be more boring and confusing than the classes of other language skills.

The German grammar textbook being developed was designed based on students' needs analysis with error analysis approach. Learners' error tendencies are given stronger emphasis in this grammar textbook, aiming that the occurrence of learners' errors can be minimized. However, the widely available grammar textbooks are merely focused on the grammatical concepts without any maximum effort in accommodating the learners' needs. It is believed that this phenomenon can affect students' motivation in learning German grammar. When students feel that the book suits their needs and condition, they are more likely to enjoy learning and to think that the book is easier to be studied. This is in correspond to the arguments from Gutiérrez \& Fernández (2014) and Van Etten et al. (2008) that one of the contributing factors in students' academic motivation is the technical materials used. Imswatama \& Lukman (2018), Satinem et al. (2020), and Abduh (2018) asserted the importance of doing learners' needs analysis prior to develop teaching materials so that they can accommodate what learners need when learning a foreign language.

The increase in students' academic motivation is accompanied with the increase in German grammar comprehension, as shown in Table 3. This can be seen from the results of correlation analysis elaborated in Table 7 that academic motivation is positively correlated with students' grammar comprehension, or in this case it is regarded as the learning outcome variable. The findings are in line with the previous studies showing that one of the contributing factors in learning outcome is the learners' own academic motivation (Jian et al., 2018; Lin \& Chen, 2017). Those studies explained that to increase students' learning outcome, teacher should focus not only on delivering the materials and thinking how students can understand it, but also making students like the materials so that it will lead to a positive effect on students' academic motivation.

The use of contrastive analysis in explaining the materials in the grammar textbook can help students understand not only the grammar, but also the linguistic processes in the target language. It can be seen from the data in Tables 5 and 6 showing that there was a significant increase in students' linguistic understanding after the treatment was given. This factor is considered to highly contribute to the rise of students' learning outcome as what is shown in Table 7 that the linguistic understanding variable has a positive correlation with the learning outcome variable. It means that the higher the students' linguistics understanding is, the better their learning outcome will be. The findings are in line with the previous researches showing that linguistics is an integral part of the foreign language teaching and learning process (Dewaele et al., 2019; Mantasiah et al., 2020; Mantasiah et al., 2018). Therefore, in teaching a foreign language, teacher has to facilitate the learners to have basic linguistic understanding.

\section{Conclusion}

Incorporating linguistic approaches in composing a grammar textbook of a foreign language is more likely to positively affect students' academic motivation, learning outcome, and linguistic understanding. The use of error analysis, as one of the applied linguistics approaches, shows a tendency for affecting students' learning motivation since this approach can be used as a mean of analyzing learners' needs in learning grammar. It becomes the basis of developing the current grammar textbook. The rise of the students' academic motivation has a positive effect on their learning outcome. In addition, the use of contrastive analysis in the grammar textbook's development process can give basic linguistic understanding to the learners and the findings 
showed that the students' linguistic understanding variable has a positive correlation with the learning outcome variable. Thus, both approaches are considered effective and can be integrated in the development of the grammar textbook.

Declaration of conflicting interest

The authors declare that there is no conflict of interest in this work.

Funding acknowledgement

This research was funded by the Ministry of Research and Technology/National Research and Innovation Agency (RISTEK-BRIN) of the Republic of Indonesia through the research grant (PTUPT) (Grant Number: 2225/ UN36.11/ LP2M/ 2020).

\section{References}

Abduh, A. (2018). Lecturers' perceptions on factors influencing the implementation of bilingual instruction in Indonesian universities. Journal of Applied Research in Higher Education.

Chen, H. (2020). A Contrastive Analysis of Classroom-Based Language Assessments. English Language Teaching, 13(5), 110-114.

Dehghani, A. P., Bagheri, M. S., Sadighi, F., \& Tayyebi, G. (2016). Investigating difficulty order of certain English grammar features in an Iranian EFL setting. International Journal of English Linguistics, 6(6), 209-220.

Dewaele, J. M., Chen, X., Padilla, A. M., \& Lake, J. (2019). The flowering of positive psychology in foreign language teaching and acquisition research. Frontiers in psychology, 10, 2128.

Dewi, N. K. A. P., Adnyani, L. D. S., \& Wahyuni, L. G. E. (2020). Describing Camtasia Video As Learning Media: An Analysis of Response in EFL Context. Journal of Education Research and Evaluation, 4(2), 165-170.

Drakulić, M. (2019). Exploring the Relationship between Students' Perceptions of the Language Teacher and the Development of Foreign Language Learning Motivation. Theory and Practice in Language Studies, 9(4), 364-370.

Gutiérrez, J. M., \& Fernández, M. D. M. (2014). Applying augmented reality in engineering education to improve academic performance \& student motivation. The International journal of engineering education, 30(3), 625-635.

Hasmawati, H., Mantasiah, R., \& Yusri, Y. (2020). A Contrastive Analysis of the Use of Prepositions in German and Indonesian. Eralingua: Jurnal Pendidikan Bahasa Asing dan Sastra, 4(1), 106-112.

Imswatama, A., \& Lukman, H. S. (2018). The effectiveness of mathematics teaching material based on ethnomathematics. International Journal of Trends in Mathematics Education Research, 1(1), 35-38.

Ismail, H., Rahmat, A., \& Emzir, E. (2020). The Effect of Moodle E-Learning Material on EFL Reading Comprehension. International Journal of Multicultural and Multireligious Understanding, 7(10), 120-129.

Jabbarova, A. (2020). The Importance of Intercultural Communicative Competence in the Development of Language Skills. Архив Научных Публикащий JSPI, 1-4.

Jiang, Y., Rosenzweig, E. Q., \& Gaspard, H. (2018). An expectancy-value-cost approach in predicting adolescent students' academic motivation and achievement. Contemporary Educational Psychology, 54, 139-152. 
Karim, A., Mohamed, A. R., Ismail, S. A. M. M., Shahed, F. H., Rahman, M. M., \& Haque, M. H. (2018). Error analysis in EFL writing classroom. International Journal of English Linguistics, 8(4), 122-138.

Khansir, A. A., \& Pakdel, F. (2019). Contrastive analysis hypothesis and second language learning. Journal of ELT Research: The Academic Journal of Studies in English Language Teaching and Learning, 35-43.

Kissau, S., Davin, K., Wang, C., Haudeck, H., Rodgers, M., \& Du, L. (2019). Recruiting foreign language teachers: An international comparison of career choice influences. Research in Comparative and International Education, 14(2), 184-200.

Lin, M. H., \& Chen, H. G. (2017). A study of the effects of digital learning on learning motivation and learning outcome. Eurasia Journal of Mathematics, Science and Technology Education, 13(7), 3553-3564.

Lo Bianco, J., \& Slaughter, Y. (2017). Bilingual and multilingual education. Springer International Publishing.

Malik, A. R., \& Asnur, M. N. A. (2019). Using Social Media as A Learning Media of Foreign Language Students In Higher Education. Bahtera: Jurnal Pendidikan Bahasa Dan Sastra, 18(2), 166-75.

Mantasiah, R, Yusri. Y., \& Jufri J. (2018). The Development of Grammar Teaching Material using Error and Contrastive Analysis (A Linguistic Approach in Foreign Language Teaching). TESOL International Journal, 13 (3), 2-11.

Mantasiah, R. (2020). Semantic Feature Analysis Model: Linguistics Approach in Foreign Language Learning Material Development. International Journal of Instruction, 13(1), 185196.

Mantasiah, R. (2020). Semantic Feature Analysis Model: Linguistics Approach in Foreign Language Learning Material Development. International Journal of Instruction, 13(1), 185196.

Mantasiah, R., \& Anwar, M. (2020, December). A Preliminary Study in Developing a Contrastive and Error Analyses-based German Grammar Textbook. In 4th International Conference on Language, Literature, Culture, and Education (ICOLLITE 2020) (pp. 419-424). Atlantis Press.

Mantasiah, R., Amir, A., Yusri, Y., \& Anwar, M. (2019). Analisis Kebutuhan Penyusunan Buku Ajar Tata Bahasa Jerman. Eralingua: Jurnal Pendidikan Bahasa Asing dan Sastra, 3(2).

Mantasiah, R., Yusri, Y., Syaputra, A. F., Angreany, F., \& Hasmawati, H. (2020). Verb Conjugation in Different Languages: A Preliminary Study in Developing German Grammar Book Based Contrastive Analysis. Eralingua: Jurnal Pendidikan Bahasa Asing dan Sastra, 4(2), 184-197.

Mantasiah, R., Yusri, Y., Syaputra, A. F., Angreany, F., \& Hasmawati, H. (2020). Verb Conjugation in Different Languages: A Preliminary Study in Developing German Grammar Book Based Contrastive Analysis. Eralingua: Jurnal Pendidikan Bahasa Asing dan Sastra, 4(2), 184-197.

Melo-Pfeifer, S., \& Chik, A. (2020). Multimodal linguistic biographies of prospective foreign language teachers in Germany: reconstructing beliefs about languages and multilingual language learning in initial teacher education. International Journal of Multilingualism, 124. 
Natalya, L., \& Purwanto, C. V. (2018). Exploratory and confirmatory factor analysis of the academic motivation scale (AMS)-Bahasa Indonesia. Makara Human Behavior Studies in Asia, 22(1), 29-42.

Nazila, D. K., Adisaputera, A., \& Saragih, A. (2020). Development of Teaching Material for Short Story Writing Experience Based on 7th Grade Students of Junior High School 2 Kejuruan Muda. Budapest International Research and Critics in Linguistics and Education (BirLE) Journal, 3(2), 1137-1150.

Nurhikmah, A., Basri, M., \& Abduh, A. (2020). Bilingual Communicative Competence Development of the Students in Indonesian Higher Education. The Asian EFL Journal, 27(2.3), 172-187.

Romadloni, A., \& Mantasiah, R. (2017). Intercultural approach in foreign language learning to improve students' motivation. Senior Editors, 61.

Rosmaladewi, R., \& Abduh, A. (2017). Collaborative Teaching Cultures of English Lecturers in Indonesian Polytechnics. International Journal of Language Education, 1(1).

Saito, A., \& Maeda, J. (2018). Engineering students' beliefs about foreign language learning and school career. The Asian Journal of Applied Linguistics, 5(2), 187-202.

Satinem, S., Juwati, J., \& Noermanzah, N. (2020). Developing Teaching Material of Poetry Appreciation Based on Students Competency Analysis. English Review: Journal of English Education, 8(2), 237.

Soler, I. G., \& Tecedor, M. (2018). Foreign language teaching assistant training: a contrastive analysis of trainers and trainees' perspectives. Hispania, 101(1), 38-54.

Staub, D., \& Kirkgöz, Y. (2019). Standards Assessment in English Language Teacher Education. Novitas-ROYAL (Research on Youth and Language), 13(1), 47-61.

Suhono, S. (2017). An analysis of written error among efl students of english proficiency level of international program. Pedagogy: Journal of English Language Teaching, 4(1), 72-81.

Suparsa, I. N., Mantra, I. B. N., \& Widiastuti, I. A. M. S. (2017). Developing learning methods of Indonesian as a foreign language. International Journal of Social Sciences and Humanities (IJSSH), 1(2), 51-57.

Uysal, N. D., \& Aydin, S. (2017). Foreign Language Teachers' Perceptions of Error Correction in Speaking Classes: A Qualitative Study. Qualitative Report, 22(1).

Vallerand, R.J., Pelletier, L.G., Blais, M.R., \&Briere, N.M. (1992). The academic motivation scale: A meas-ure of intrinsic, extrinsic, and amotivation in education. Educational and Psychological Measurement,52(4), 1003-1007.doi: 10.1177/0013164492052004025

Van Etten, S., Pressley, M., McInerney, D. M., \& Liem, A. D. (2008). College seniors' theory of their academic motivation. Journal of Educational Psychology, 100(4), 812.

Vannestål, M. E., \& Lindquist, H. (2007). Learning English grammar with a corpus: A Preliminary Study in A. Grammar Book Based Contrastive Analysis. ReCALL: the Journal of EUROCALL, 19(3), 329.

Wiens, P. D., Andrei, E., Anassour, B., \& Smith, A. (2018). Expanding Circle: The Case of Nigerien EFL Teachers' English, Training and Career Satisfaction. TESL-EJ, 22(2), n2.

Zhou, W. (2020, October). Education for Bilingual Children in the Age of Artificial Intelligence. In International Conference on Machine Learning for Cyber Security (pp. 436-442). Springer, Cham. 